\title{
CONDITIONS OF MICROELEMENTS EXCHANGE PROCESSES IN WOMEN'S PLACENTS IN INTRAUTERINE INFECTION OF THE FETUS
}

DOI: $10.36740 /$ WLek202007123

\author{
Iryna M. Nikitina', Svitlana A. Smiian', Kateryna 0. Kondratiuk' ${ }^{1}$, Natalia V. Kalashnyk', Anzhelika A. Shevel ${ }^{3}$ \\ 'SUMY STATE UNIVERSITY, SUMY, UKRAINE \\ ${ }^{2}$ BOGOMOLETS NATIONAL MEDICAL UNIVERSITY, KYIV, UKRAINE \\ ${ }^{3}$ SUMY NATIONAL AGRARIAN UNIVERSITY, SUMY, UKRAINE
}

\begin{abstract}
The aim: to study the content of trace elements ( $\mathrm{Fe}, \mathrm{Cu}, \mathrm{Zn}, \mathrm{Co}, \mathrm{Cr}, \mathrm{Ni}, \mathrm{Pb})$ in the placenta of pregnant healthy women and with signs of intrauterine infection of the fetus, features of transplacental transmission of infectious process from mother to fetus and to investigate the role of the placenta in trace element supply of the fetus.

Materials and methods. 43 pregnant women between the aged 16 to 40 years were monitored, including 12 with physiological pregnancy (group 1) and 31 with signs of STI (group 2). All pregnant women underwent standard comprehensive examination, evaluation of fetal cardiac output and non-stress testing using cardio-tocography (CTG) in the third trimester. The group of pregnant women with signs of fetal ulcers included women whose pregnancy was complicated by chronic fetoplacental dysfunction (FPD), infectious lesions of the fetoplacental complex, which were diagnosed on the basis of ultrasound signs of placenta, syndrome of infectious and surrounding infections.

Results: The content of essential trace elements in the placenta of the main group was significantly lower than in the placenta of the control group. There was a decrease in the concentration of iron by $32 \%$, zinc - by $46 \%$, nickel - by $44 \%$, copper more than tripled, chromium - 4 times. Deficiency of essential trace elements (iron, zinc, copper, chromium, nickel) and elevated lead content in the placenta leads to the formation of conditions for the development of placental dysfunction, the progression of which leads to fetal distress, developmental delay syndrome and antenatal fetal death.

Conclusions: 1 . One of the links in the pathogenesis of intrauterine infection in the fetus is the imbalance of essential trace elements in the system «mother - placenta - fetus». 2. Pregnant women with signs of intrauterine infection are characterized by a deficiency of serum $\mathrm{Fe}, \mathrm{Cu}, \mathrm{Zn}$, Ni and an increased content of $\mathrm{Pb}$, Cr and $\mathrm{Co}$ compared with pregnant women with physiological pregnancy. 3. Umbilical cord blood of women with evidence of fetal fetal infection also has a reduced content of iron, copper, zinc and high levels of lead, cobalt and chromium. 4. Disruption of placental function in intrauterine infection of the fetus is caused by reduced content of iron, zinc, copper, nickel and lead accumulation.
\end{abstract}

KEY WORDS: trace elements, placenta, intrauterine infection of the fetus

Wiad Lek. 2020;73(7):1434-1437

\section{INTRODUCTION}

The problem of intrauterine infection is one of the leading obstetric practices. According to the Ministry of Health of Ukraine, only $6 \%$ of practically healthy children are born in our country today, every third child has a physical or mental health disability, and every second is a carrier of cytomegalovirus, herpes and other infections. Infectious pathology is diagnosed in 50-60\% of hospitalized full-term and $80 \%$ of premature infants [1]. According to the results of pathoanatomical studies, in $38 \%$ of deceased children, infection is the main cause of death or concomitant nosology, which complicates the course of the underlying disease $[1,2]$.

The basis of the processes of interaction between mother and fetus organisms during pregnancy is the formation of a single functional system "mother-placenta-fetus». The placenta is a link in the formation of a complex that promotes the preservation and progression of pregnancy. In intrauterine infection (IUD) of the fetus, various medical, environmental, social, biological factors are combined, accompanied by metabolic disorders, imbalance of trace elements metabolism, development of tissue hypoxia in the mother and fetus $[3,4]$. In the vast majority of women, there are significant shifts in the immune, coagulation, neuroendocrine systems, which correlates with changes in the fetus and tissues of the fetoplacental complex (FPC), especially the placenta $[5,6]$. The first reactions of the body in response to the development of trace elements are manifested in the preclinical stages. Temporarily latent pathological process is manifested by pseudoadaptation syndrome, then by maladaptation syndrome of the mother and FPC. In its clinical manifestations include transient hypertonicity of the uterine body, placental hyperplasia, chronic fetal hypoxia.

The progression of this process leads to dysfunction, premature aging of the placenta, delayed fetal growth and other perinatal complications $[7,8,9]$.

Essential trace elements (MEs), which include zinc, iron, cobalt, chromium, copper, manganese, which ensure the functioning of the placenta, membrane permeability, active 
Table II. The content of trace elements in the placenta

\begin{tabular}{cccc}
\hline ME & $\begin{array}{c}\text { The placenta of women with signs of } \\
\text { fetal IUD, } \mathbf{~} \mathbf{g} / \mathbf{g}\end{array}$ & $\begin{array}{c}\text { The placenta of women with } \\
\text { physiological pregnancy, } \mathbf{m c g} / \mathbf{g}\end{array}$ & $\mathbf{p}<\mathbf{0 , 0 5}$ \\
\hline $\mathrm{Fe}$ & $14439,0 \pm 3094,0$ & $21267,83 \pm 1262,93$ & $\mathrm{p}<0,05$ \\
\hline $\mathrm{Zn}$ & $2748,65 \pm 184,43$ & $5093,73 \pm 437,31$ & $\mathrm{p}<0,001$ \\
\hline $\mathrm{Cu}$ & $96,93 \pm 11,04$ & $309,58 \pm 77,58$ & $\mathrm{p}<0,01$ \\
\hline $\mathrm{Co}$ & $164,45 \pm 39,72$ & $64,53 \pm 15,57$ & $\mathrm{p}<0,05$ \\
\hline $\mathrm{Cr}$ & $43,51 \pm 7,46$ & $169,41 \pm 49,49$ & $\mathrm{p}<0,05$ \\
\hline $\mathrm{Ni}$ & $44,83 \pm 4,94$ & $78,0 \pm 12,2$ & $\mathrm{p}<0,05$ \\
\hline $\mathrm{Pb}$ & $72,16 \pm 14,97$ & $37,08 \pm 5,7$ & $\mathrm{p}<0,05$ \\
\hline $\mathrm{Mn}$ & $0,059 \pm 0,011$ & $0,041 \pm 0,05$ & - \\
\hline
\end{tabular}

transport of chemicals, fetal oxygenation, energy and other types of metabolism. Their antagonists are heavy metals that can bind to amino acids, enzymes, nucleic acids, $\mathrm{SH}$ groups of blood cell proteins $[10,11]$. Heavy metal cations significantly affect the functional state of cell mitochondria, disrupting their metabolism and membrane permeability, which determining the activity of enzymes. Suppression of the activity of enzymes of biological oxidation by toxic metal inhibitors or damage to the membrane structures of mitochondria and other cellular elements is accompanied by hemocoagulation disorders with impaired blood coagulation system, and decrease ability of the placenta to absorb oxygen. These phenomena are one of the causes of tissue hypoxia and disorders of the compensatory-adaptive mechanisms in the placenta and fetoplacental complex as a whole $[12,13]$.

\section{THE AIM}

To study the content of trace elements $(\mathrm{Fe}, \mathrm{Cu}, \mathrm{Zn}, \mathrm{Co}$, $\mathrm{Cr}, \mathrm{Ni}, \mathrm{Pb}$ ) in the placenta of healthy pregnant women with signs of intrauterine fetal infection, features of transplacental transmission of infectious process from mother to fetus and to investigate the role of the placenta in trace element supply of the fetus.

\section{MATERIALS AND METHODS}

The study was conducted at the Sumy Regional Clinical Perinatal Center and the Department of Obstetrics and Gynecology of Sumy State University during 2012-2018. In total, 43 pregnant women aged 16 to 40 years were monitored, including 12 with physiological pregnancy (group 1) and 31 with signs of STI (group 2). All pregnant women underwent standard comprehensive examination, evaluation of fetal cardiac output and non-stress testing using cardio-tocography (CTG) in the third trimester. Ultrasound was performed by transabdominal scanning using an Aloka SSD-1800 ultrasonic portable scanner (Toshiba, Japan) with a 3.5 to $10 \mathrm{MHz}$ probe. When determining the pathological biophysical profile of the fetus (BPP), Doppler blood flow velocity was performed in the umbilical artery, the middle cerebral artery. This study was approved by the ethics committee of the Sumy State University, Ukraine. All procedures were carried out in accordance with the ethical standards of the responsible committee on human experimentation and with the Helsinki Declaration of 1975, as revised in 2000.

The group of pregnant women with signs of fetal ulcers included women whose pregnancy was complicated by chronic fetoplacental dysfunction (FPD), infectious lesions of the fetoplacental complex, which were diagnosed on the basis of ultrasound signs of placenta, syndrome of infectious and surrounding infections.

The content of trace elements $(\mathrm{Fe}, \mathrm{Cu}, \mathrm{Zn}, \mathrm{Co}, \mathrm{Cr}, \mathrm{Ni}$, $\mathrm{Pb}$ ) was determined by the method of atomic absorption spectrophotometry on the C-115M1 spectrophotometer manufactured by NGO Selmi (Ukraine). The material for the study was taken from central part of placenta immediately post delivery of which, a section of tissue was cut out, pre-determining the weight, burned, and ash was obtained. The arithmetic mean (M) and the arithmetic mean (m) were determined for all indicators. Using Student's t test $(t)$, the confidence index $(p)$ was determined and the correlation (r) was calculated.

\section{RESULTS AND DISCUSSION}

The content microelements of in the placenta of women with signs of fetal intrauterine infection compared with the content in the placenta of women with physiological pregnancy had its differences. Thus, the content of essential trace elements in the placenta of the main group was significantly lower than in the placenta of the control group. There was a decrease in iron concentration by $32 \%$ ( $\mathrm{p}<0.05)$, zinc - by $46 \%(\mathrm{p}<0.001)$, nickel - by $44 \%$ ( $\mathrm{p}$ $<0.05)$, copper more than three times $(\mathrm{p}<0.01)$, chromium - 4-fold $(\mathrm{p}<0.05)$ (Table I).

Reducing the content of vital microelements indicates that infectious tissue damage leads to the partial release of trace elements from cells through damaged membranes. This mechanism is possible in inflammatory and necrotic processes in the placental tissue. The exceptions were cobalt 
and manganese, whose contents were $2.5(\mathrm{p}<0.05)$ and 1.5 times higher in the placenta of the main group, respectively. These metals are known as activators of redox reactions, a number of enzymes. In our opinion, the accumulation of manganese and cobalt in the placenta of women with signs of fetal infection is associated with the activation of compensatory responses.

The quantitative determination of the toxic content of lead in the placenta showed that the fetal lead was $50 \%$ significantly higher $(p<0.05)$ than in the control group. Intense deposition of lead in the placenta on the background of fetal IUD has a negative effect on the respiratory, trophic, protective functions of the placenta. This phenomenon contributes to the increase in the frequency of fetoplacental insufficiency and infectious defeat of the fetoplacental complex.

When studying the content of IU, in order to reduce their concentration in the placenta of women with physiological pregnancy, the arrangement was as follows: $\mathrm{Fe}>\mathrm{Zn}>\mathrm{Cu}$ $>\mathrm{Cr}>\mathrm{Ni}>\mathrm{Co}>\mathrm{Pb}>\mathrm{Mn}$.

In the placenta of women with signs of fetal IUI, the location of the IU was as follows: $\mathrm{Fe}>\mathrm{Zn}>\mathrm{Co}>\mathrm{Cu}>\mathrm{Pb}$ $>\mathrm{Ni}>\mathrm{Cr}>\mathrm{Mn}$.

In the main group, there is a direct (strong) correlation: for $\mathrm{Zn}$, with $\mathrm{Ni}$; for $\mathrm{Cr}-$ with $\mathrm{Co}, \mathrm{Pb}$; for $\mathrm{Mn}$ - with $\mathrm{Cu}(\mathrm{p}<0.001)$. A direct correlation of mean strength was found for $\mathrm{Zn}$ - with $\mathrm{Pb}, \mathrm{Cu}$, Co; for $\mathrm{Mn}$ - with $\mathrm{Co}$; for $\mathrm{Co}$ - with $\mathrm{Pb}$; for $\mathrm{Cu}$ with $\mathrm{Pb}$ $(p<0.01)$. We observe a weak (direct) correlation for $\mathrm{Cr}$ with $\mathrm{Co}$; for $\mathrm{Ni}$ - with $\mathrm{Cr}(\mathrm{p}<0.05)$. No correlation was found between these elements, which could indicate a membrane-toxic and enzymatic effect and impaired structure and function of lining tissue cells and determine the fetal condition of the newborn. From the above it shows that the deficiency of essential trace elements (iron, zinc, copper, chromium, nickel) and the increased content of toxic ME of lead in the placenta leads to the formation of conditions for the development of placental dysfunction, the progression of which leads to fetal distress, developmental delay syndrome and fetal death. In the physiological course of pregnancy, it is possible to assume that there are certain mechanisms in the placenta for protection against toxic ME and preservation of vital ME that ensure the satisfactory functioning of fetoplacental complex.

\section{CONCLUSIONS}

1. One of the links in the pathogenesis of fetal intrauterine infection is the imbalance of essential trace elements in the system «mother - placenta - fetus».

2. Pregnant women with signs of intrauterine infection are deficient in serum iron, copper, zinc, nickel, and elevated lead, chromium and cobalt content compared to pregnant women with physiological pregnancy.

3. Umbilical cord blood of women with evidence of fetal infection also has a reduced content of iron, copper, zinc and high levels of lead, cobalt and chromium. Therefore, the deficiency of essential trace elements in the body of a pregnant woman is accompanied by their deficiency in the body of the fetus.
4. Disruption of placental function in intrauterine infection of the fetus is caused by reduced content of iron, zinc, copper, nickel and lead accumulation.

\section{REFERENCES}

1. Zaporozhan V.N., Gozhenko A.I., Mishhenko V.P., et al. Sovremennye vzglyady na gestaczionnye mikroelementozy [Modern views on gestational microelementoses]. Visnik asocziacziyi akusherivginekologiv Ukrayini. 2001; 1: 6-11. (Ru)

2. Mishhenko V.P. Problema mikroelementozov v akusherstve i perinatologii. [The problem of microelements in obstetrics and perinatology]. Mezhdunarodnyj med.zhurnal. 2011;2: 38-41. (Ru)

3. Nikogosyan L.R. Osoblivosti klinichnogo perebigu gestaczijnikh proczesiv pri bagatovoddi u zhinok z mikroelementozami [Features of clinical interruption of gestational processes in case of bagata in women with microelementoses]. Doctor of Medical Sciences Paper. Odesa. 2006, 19. (UA)

4. Sherer V.V. Dismikroelementoz pri sindromi zagrozi pererivannya vagitnosti ta jogo korekcziya [Dysmicroelementosis in case of threatening syndrome, overdriving of vaginosis and that correction]. Doctor of Medical Sciences Paper. Odesa. 2006, 18. (UA)

5. Nikitina I., Boychuk A., Babar T., Dunaeva M. Prediction of threats to multiple pregnancy interruption depending on the cause of its occurrence. Research Journal of Pharmaceutical, Biological and Chemical Sciences. 2016; 7: $764-771$.

6. Nikitina I., Boychuk A., Kalashnik N., et al. Immunomorphological features of the placenta in multiple pregnancies. Georgian medical news. 2016; 6: 12-17.

7. BelousovA.Yu.,MartirosyanS.V.Opredeleniesoderzhaniya essenczialnykh mikroelementov v krovi beremennykh zhenshhin, prozhivayuchikh v usloviyakh krajnego severa [Determination of the content of essential trace elements in the blood of pregnant women living in the extreme north]. Zdorove zhenshhiny. 2006; 2: 54-55. (Ru)

8. Batman Yu.A. Soderzhanie makro-i mikroelementov v pupovinnoj krovi u novorozhdennykh razlichnykh klinicheskikh grupp [The content of macro- and microelements in cord blood in newborns of various clinical groups]. Zdorove zhenshhiny. 2007; 2: 242-246. (Ru)

9. Fofanova I.Yu., Prilepskaya V.N. Soderzhanie ryada mikroelementov v syvorotke krovi v pervoj polovine beremennosti u beremennykh s urogenitalnym mikoplazmozom [The content of a number of trace elements in blood serum in the first half of pregnancy in pregnant women with urogenital mycoplasmosis]. Ginekologiya. 2005. (Ru)

10. Devyatova E.A., Gordeev A.N., Burenkova I.A. Osobennosti nakopleniya mikroelementov $v$ syvorotke krovi pri oslozhnennom techenii beremennosti [Features of the accumulation of trace elements in blood serum in complicated pregnancy]. Vesnik RGMU. 2007; 2: 340-341. (Ru)

11. Chajka V.K., Batman Yu.A., Kozinskij A.V. Izuchenie mikroelementozov u beremennykh, prozhivayushhikh v ekologicheski neblagopriyatnykh rajonakh [The study of microelements in pregnant women living in ecologically unfavorable areas]. Mediko-soczialnye problemy semi. 2006; 11. 6: 22-24. (Ru)

12. Mishhenko V.P., Mishhenko I.V. Priobretyonnye mikroelementozy u beremennykh zhenshhin s khronicheskim pielonefritom [Acquired microelementoses in pregnant women with chronic pyelonephritis]. Visnik morskoyi mediczini. 2006; 3: 18-21. (Ru)

13. Boiko I.V., Nikitina I.M., Babar T.V., Boiko A.V. The problem of miscarriage in multiple pregnancy. Wiad. Lek.. 2018; 7: 1195-1199. 
The work is carried out within the framework of the research work "Optimization of diagnosis and prevention of diseases of the reproductive system and development of pathogenically grounded methods for their correction" (state registration number 011U001801). The work was not financed by external sources.

\section{ORCID and contributionship:}

Iryna M. Nikitina: 0000- 0001-6595-2502 ${ }^{A, E, F}$

Svitlana A. Smiian: 0000-0002-7679-2302 B,D

Kateryna O. Kondratiuk: 0000-0001-5915-1821 B,C

Natalia V. Kalashnyk: 0000-0003-1515-9105 B,C

Anzhelika A. Shevel: 0000-0002-7129-1859 ${ }^{D}$

\section{Conflict of interest:}

The Authors declare no conflict of interest

\section{CORRESPONDING AUTHOR}

Iryna M. Nikitina

Sumy State University

12, Rymskogo-Korsakova st.,

40030, Sumy, Ukraine

tel: +380662947360

e-mail:nikitina1med@gmail.com

Received: 03.03.2019

Accepted: 18.06 .2020

A - Work concept and design, B - Data collection and analysis, C - Responsibility for statistical analysis, D-Writing the article, $\mathbf{E}$-Critical review, $\mathbf{F}$ - Final approval of the article 